\title{
Synthesis and Fungicidal Activity of $\alpha$-Cyanoacetamide Derivatives: Discovery of a New Rice Blast Fungicide, Diclocymet (S-2900)
}

\author{
Akio Manabe, ${ }^{*}$ Kiyoto Maeda, Masayuki Enomoto, Hirotaka TaKano, \\ Tsuguhiro KATOH, Yoshimi YAMADA and Yukio OGURI \\ Agricultural Chemicals Research Laboratory, Sumitomo Chemical Co., Ltd., \\ 4-2-1, Takatsukasa, Takarazuka, Hyogo 665-8555, Japan
}

(Received January 22, 2002 ; Accepted April 19, 2002)

\begin{abstract}
In order to search for a new systemic rice blast fungicide, a number of $N$-benzyl- $\alpha$-cyanoacetamide derivatives and related compounds were prepared and their preventive activity against rice blast, Magnaporthe grisea was examined both in a foliar spray test and in a soil drench test. Several $\mathrm{N}$ [1-(substituted-phenyl)ethyl]- 2-cyano-3,3-dimethyl-butanamides and -2-pentenamides showed high activity in both tests. Among them, $(R S)$-2-cyano- $N$-[(R)-1-(2,4-dichlorophenyl)ethyl]-3,3-dimethylbutyramide (diclocymet, S-2900) was selected as a practical new systemic rice blast fungicide, which shows potent fungicidal activity with little crop injury.
\end{abstract}

Key words: rice blast fungicide, systemic activity, $\alpha$-cyanoacetamide derivatives, stereoisomer, diclocymet, S-2900.

\section{INTRODUCTION}

It has been reported that certain kinds of sterically hindered $N$-benzylbutanamides such as 2-bromo- $N$-[1(4-chlorophenyl)ethyl]-3,3-dimethylbutanamide 1 were effective in controlling rice blast. ${ }^{1)}$ As part of a continuing screening program to search for a new systemic rice blast fungicide, we reinvestigated the efficacy of 1 against rice blast and found that its activity in a soil drench test was moderate, although it showed good preventive activity in a foliar spray test. This result might be attributed to its low systemic action due to a high degree of hydrophobicity. On the basis of this working hypothesis, we reasoned that one could enhance its systemic action by introducing a hydrophilic group into an appropriate site on the molecule. In this context, we initiated structural modifications of $\mathbf{1}$ and found that replacement of the bromo group with the more hydrophilic cyano group (5) greatly increased the systemic action of $\mathbf{1}$ without decreasing its preventive activity. Further structural optimization from the view points of fungicidal potency and degree of phytotoxicity, including a steric structureactivity correlation study, led to the discovery of a new systemic blast fungicide, diclocymet (S-2900, $(R S)$-2-

\footnotetext{
* To whom correspondence should be addressed.

E-mail: manabe@sc.sumitomo-chem.co.jp
}

cyano- $N$ - $[(R)-1-(2,4-$ dichlorophenyl)ethyl $]-3,3-$ dimethylbutyramide, 56e). We report here the synthesis and fungicidal activity of the $\alpha$-cyanoacetamide derivatives. The mode of action of 56e will be briefly referred to.

\section{MATERIALS AND METHODS}

\section{Synthesis of Compounds}

The structures of the synthesized compounds were confirmed using ${ }^{1} \mathrm{H}$ NMR spectra, and in some cases, mass spectra. Melting points and boiling points are uncorrected.

\subsection{Synthesis of amides other than $\alpha$-cyanoacetamide compounds}

The routes to synthesize amides other than $\alpha$ cyanoacetamide compounds are shown in Fig. 1. The sulfoxide 8 and the sulfone 9 were obtained by oxidation of the sulfide 2 which was prepared by the reaction of $\mathbf{1}^{1)}$ with NaSMe. Compound $\mathbf{6}$ having a methoxy group was prepared by the reaction of the corresponding amine and the acid chloride derived from the acid, which was prepared by the reaction of the $\alpha$-bromo acid with $\mathrm{NaOMe}$. The fluorine compound $\mathbf{3}$ was obtained by the reaction of the alcohol 7 with diethylaminosulfur trifluoride, ${ }^{2)}$ which was prepared ${ }^{3)}$ by the reaction of pivalaldehyde and an isonitrile ${ }^{4)}$ in the presence of an 


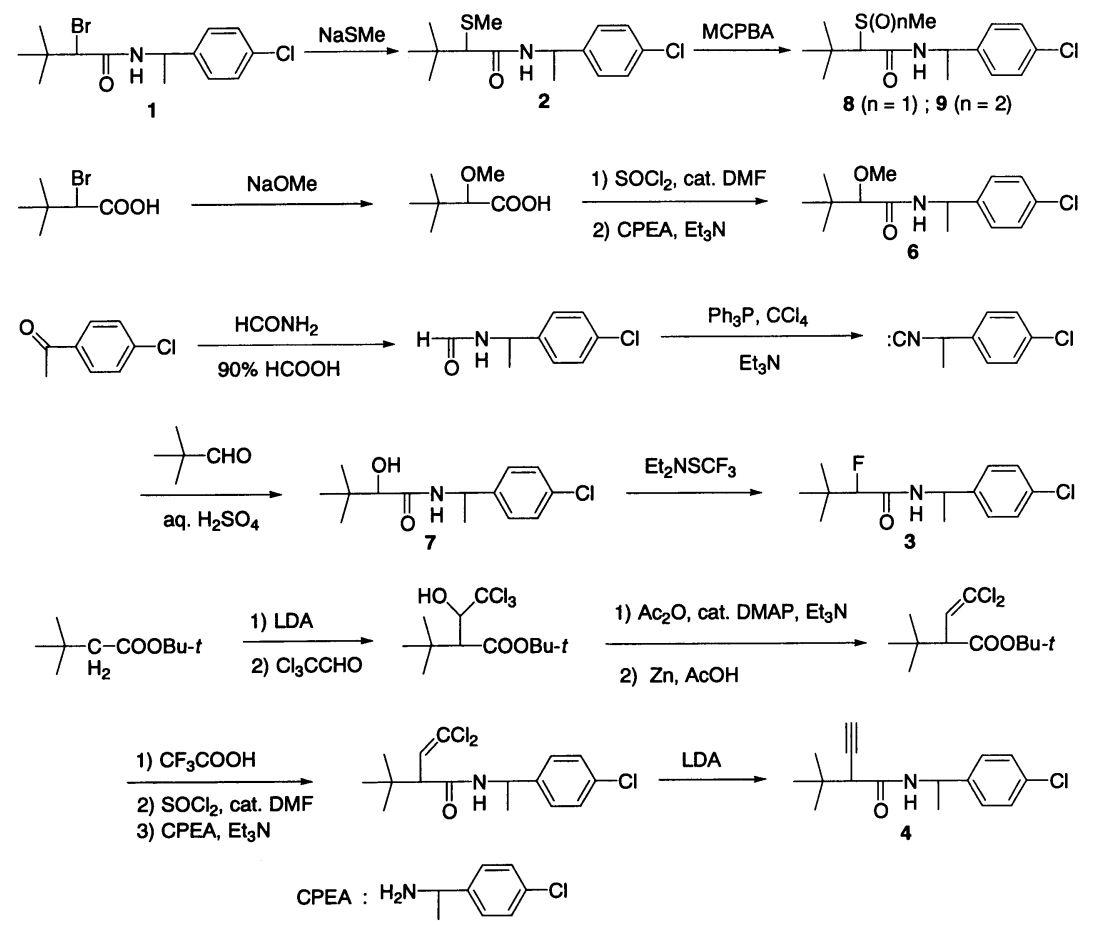

Fig. 1 Routes of synthesis for $\alpha$-functionalized amide compounds.

acid. Compound 4 having an ethynyl group was prepared by treating with lithium diisopropylamide the corresponding dichlorovinyl amide, which was obtained by the reaction of the corresponding amine and the acid chloride. Experimental details are as follows:

\subsubsection{N-[1-(4-Chlorophenyl)ethyl]-3,3-dimethyl-2- (methylsulfenyl)butanamide 2}

A mixture of $1(6.65 \mathrm{~g})$ and $\mathrm{NaSMe}(15 \%$ aq. solution, $28 \mathrm{~g}$ ) in DMF $(30 \mathrm{ml})$ was heated at $130-140^{\circ} \mathrm{C}$ (bath temperature) for $8 \mathrm{hr}$. The mixture was treated with water and extracted with ethyl acetate. The organic layer was washed twice with brine, dried and concentrated. The residue was chromatographed on silica gel (eluent, hexane-ethyl acetate $(5: 1, \mathrm{v} / \mathrm{v}))$ to give $2(2.44 \mathrm{~g}$, $41 \%)$.

\subsubsection{N-[1-(4-Chlorophenyl)ethyl]-3,3-dimethyl-2- (methylsulfinyl)butanamide 8}

To an ice-cooled solution of $2(0.60 \mathrm{~g})$ in $\mathrm{CHCl}_{3}(20$ $\mathrm{ml})$ was added dropwise a solution of $m$ chloroperbenzoic acid $(70 \%, 0.49 \mathrm{~g})$ in $\mathrm{CHCl}_{3}(10 \mathrm{ml})$. After stirring with ice-cooling for $1 \mathrm{hr}$, the mixture was treated with $\mathrm{NaHCO}_{3}$ aq. and extracted with $\mathrm{CHCl}_{3}$. The organic layer was washed with brine, dried and concentrated. The residue was subjected to a preparative TLC on silica gel (developer, hexane-THF $(1: 1$, $\mathrm{v} / \mathrm{v}))$ to give $8(0.4 \mathrm{~g}, 63 \%)$.

\subsubsection{N-[1-(4-Chlorophenyl)ethyl]-3,3-dimethyl-2- (methylsulfonyl)butanamide 9}

To a solution of $2(0.60 \mathrm{~g})$ in $\mathrm{CHCl}_{3}(20 \mathrm{ml})$ was added portionwise $m$-chloroperbenzoic acid $(70 \%, 1.08$ g). After stirring at room temperature for $1 \mathrm{hr}$, the mixture was treated with $\mathrm{NaHCO}_{3}$ aq. and extracted with $\mathrm{CHCl}_{3}$. The organic layer was washed with brine, dried and concentrated. The residue was subjected to a preparative TLC on silica gel (developer, hexane-ethyl acetate $(2: 1, \mathrm{v} / \mathrm{v}))$ to give $9(0.34 \mathrm{~g}, 51 \%)$.

1.1.4. N-[1-(4-Chlorophenyl)ethyl]-2-methoxy-3,3dimethylbutanamide 6

To an ice-cooled solution of 2-bromo-3,3dimethylbutanoic acid $(9.5 \mathrm{~g})$ in DMF $(50 \mathrm{ml})$ was added dropwise NaOMe (28\% solution in methanol, 27.4 g). Methanol was removed under reduced pressure and the residue was stirred at reflux under $\mathrm{N}_{2}$ for $6 \mathrm{hr}$. The mixture was treated with water, acidified with conc. $\mathrm{HCl}$ with ice-cooling and extracted with ethyl acetate. The organic layer was washed three times with brine, dried and distilled (bp $76-92^{\circ} \mathrm{C}$ at $0.2 \mathrm{mmHg}$ ) to give crude 2-methoxy-3,3-dimethylbutanoic acid (2.57 g). The mixture of the acid $(1.46 \mathrm{~g})$ and thionyl chloride $(1.43 \mathrm{~g})$ was stirred at room temperature in the presence of a drop of DMF and stirred at $60-70^{\circ} \mathrm{C}$ for $1 \mathrm{hr}$ to give crude 2-methoxy-3,3-dimethylbutanoyl chloride. To an ice-cooled solution of 1-(4-chlorophenyl)ethylamine $(1.56 \mathrm{~g})$ and triethylamine $(1.6 \mathrm{~g})$ was added dropwise the crude acid chloride. After stirring at room temperature for $2 \mathrm{hr}$, the mixture was washed with water, dried and concentrated. The residue was chromatographed on silica gel (eluent, hexane-ethyl acetate $(5: 1, \mathrm{v} / \mathrm{v}))$ to give 61 (the less polar diastereomer, $0.30 \mathrm{~g}$ ), followed by $6 \mathrm{~m}$ (the more polar diastereomer, $0.35 \mathrm{~g}$ ). 


\subsubsection{N-[1-(4-Chlorophenyl)ethyl]-2-hydroxy-3,3- dimethylbutanamide 7}

A mixture of 4 '-chloroacetophenone $(46.4 \mathrm{~g})$, formamide $(55.7 \mathrm{~g})$ and $90 \%$ aq. formic acid $(6 \mathrm{ml})$ was heated at $160-170^{\circ} \mathrm{C}$ for $6 \mathrm{hr}$. The mixture was treated with water and extracted with $\mathrm{CHCl}_{3}$. The organic layer was washed twice with brine, dried and concentrated. The solid residue was recrystallized from diisopropyl ether to give $N$-[1-(4-chlorophenyl)ethyl] formamide ( $39.6 \mathrm{~g}, 72 \%)$.

A mixture of the amide $(9.18 \mathrm{~g}), \mathrm{CCl}_{4}(8.01 \mathrm{~g})$, triethylamine $(5.11 \mathrm{~g})$ and triphenylphosphine $(16.3 \mathrm{~g})$ in dry $\mathrm{CHCl}_{3}$ was stirred at $60^{\circ} \mathrm{C}$ for $2.5 \mathrm{hr}$ and concentrated. The residue was triturated with hexane and filtered. The filtrate was distilled (bp $79-81^{\circ} \mathrm{C}$ at $0.55 \mathrm{mmHg}$ ) to give 1-(4-chlorophenyl)ethyl isocyanide $(6.0 \mathrm{~g}, 72 \%)$.

To an ice-cooled solution of the isocyanide $(0.83 \mathrm{~g})$ in pivalaldehyde $(5 \mathrm{ml})$ was added dropwise conc. $\mathrm{H}_{2} \mathrm{SO}_{4}$ $(0.52 \mathrm{~g})$ in water $(5 \mathrm{ml})$. After stirring at room temperature for $1 \mathrm{hr}$, the mixture was diluted with ethyl acetate, washed successively with $\mathrm{K}_{2} \mathrm{CO}_{3}$ aq. and brine, dried and concentrated. The residue was chromatographed on silica gel (eluent, hexane-ethyl acetate $(3: 1$ then $1: 1$, $\mathrm{v} / \mathrm{v}$ )) to give $7 \mathrm{l}$ (the less polar diastereomer, $0.47 \mathrm{~g}$, 35\%), followed by $\mathbf{7} \mathbf{~ m}$ (the more polar diastereomer, 0.45 g, 33\%).

\subsubsection{N-[1-(4-Chlorophenyl)ethyl]-2-fluoro-3,3- dimethylbutanamide 3}

To a solution of diethylaminosulfur trifluoride $(0.64 \mathrm{~g})$ in dry $\mathrm{CH}_{2} \mathrm{Cl}_{2}(13 \mathrm{ml})$ was added dropwise $7(1.08 \mathrm{~g})$ in dry $\mathrm{CH}_{2} \mathrm{Cl}_{2}(5 \mathrm{ml})$ with stirring at $-78^{\circ} \mathrm{C}$, and the reaction mixture was then allowed to rise to room temperature. The stirring was continued overnight and the resultant mixture was washed twice with water, dried and concentrated. The residue was chromatographed on silica gel (eluent, hexane-ethyl acetate $(10: 1, \mathrm{v} / \mathrm{v}))$ to give crude $3(0.06 \mathrm{~g})$, which was subjected to a preparative TLC on silica gel (developer, benzene) to give $3(0.03 \mathrm{~g}$, $3 \%)$.

\subsubsection{2-tert-Butyl-N-[1-(4-chlorophenyl)ethyl]-3- butynamide 4}

To a solution of diisopropylamine $(10.12 \mathrm{~g})$ in dry THF $(50 \mathrm{ml})$ was added dropwise butyllithium $(1.6 \mathrm{M}$ in hexane, $62.5 \mathrm{ml}$ ) below $0{ }^{\circ} \mathrm{C}$. The mixture was stirred at $0^{\circ} \mathrm{C}$ for $10 \mathrm{~min}$. To the mixture was added tert-butyl 3,3-dimethylbutanoate $(15.48 \mathrm{~g})$ in dry THF $(20 \mathrm{ml})$ below $0^{\circ} \mathrm{C}$ and the stirring was continued for $30 \mathrm{~min}$. To the mixture was added trichloroacetaldehyde (13.54 g) in dry THF $(20 \mathrm{ml})$ at $-60^{\circ} \mathrm{C}$. The mixture was stirred at $-60^{\circ} \mathrm{C}$ for $1 \mathrm{hr}$ and allowed to rise to room temperature with stirring overnight. The mixture was poured into ice-water, neutralized with conc. $\mathrm{HCl}$ and extracted with ether. The organic layer was washed with water, dried and distilled (bp $105-110^{\circ} \mathrm{C}$ at 0.4 $\mathrm{mmHg}$ ) to give tert-butyl 2-tert-butyl-4,4,4-trichloro-3- hydroxybutanoate $(15.6 \mathrm{~g}, 49 \%)$.

To an ice-cooled solution of the hydroxy ester $(9.58 \mathrm{~g})$, triethylamine (4.64 g) and 4-dimethylaminopyridine $(0.77 \mathrm{~g})$ in dry THF $(100 \mathrm{ml})$ was added acetic anhydride $(3.99 \mathrm{~g})$. After stirring at room temperature for $2 \mathrm{hr}$, the mixture was diluted with ether, washed successively with $\mathrm{HCl}$ aq., $\mathrm{NaHCO}_{3}$ aq. and water, dried and concentrated to give tert-butyl 3-acetyloxy-2-tert-butyl-4,4,4-trichlorobutanoate $(9.73 \mathrm{~g}, 90 \%)$.

To a solution of the tert-butyl ester $(8.65 \mathrm{~g})$ in acetic acid $(100 \mathrm{ml})$ was added zinc powder $(18.38 \mathrm{~g})$ and the mixture was stirred at $60^{\circ} \mathrm{C}$ for $7 \mathrm{hr}$. The mixture was filtered and washed with ether. The filtrate was washed successively with $5 \% \mathrm{NaOH}$ aq., $\mathrm{NaHCO}_{3}$ aq. and water, dried and concentrated to give tert-butyl 2-tert-butyl4,4-dichloro-3-butenoate (5.68 g, 89\%).

To a solution of the tert-butyl ester $(3.93 \mathrm{~g})$ in $\mathrm{CH}_{2} \mathrm{Cl}_{2}$ $(10 \mathrm{ml})$ was added trifluoroacetic acid $(5 \mathrm{ml})$ and the solution was allowed to stand at room temperature overnight. The mixture was washed twice with water, dried and concentrated to give 2-tert-butyl-4,4-dichloro3-butenoic acid $(3.12 \mathrm{~g})$. To a solution of the acid $(2.7$ g) in dry benzene was added dropwise thionyl chloride $(2.28 \mathrm{~g})$ and a drop of DMF. The mixture was heated under reflux for $3 \mathrm{hr}$ and filtered. The filtrate was concentrated to give 2-tert-butyl-4,4-dichloro-3-butenoyl chloride $(2.78 \mathrm{~g})$. To an ice-cooled solution of 1-(4chlorophenyl)ethylamine $(1.55 \mathrm{~g})$ and triethylamine $(1.21 \mathrm{~g})$ in dry THF was added the acid chloride $(2.30 \mathrm{~g})$. After stirring at room temperature for $2 \mathrm{hr}$, the mixture was treated with water and extracted with ethyl acetate. The organic layer was washed with water, dried and concentrated. The residue was chromatographed on silica gel (eluent, $\mathrm{CHCl}_{3}$ ) to give 2-tert-butyl-4,4dichloro- $N$-[1-(4-chlorophenyl)ethyl]-3-butenamide.

To a solution of diisopropylamine $(0.81 \mathrm{~g})$ in dry THF $(10 \mathrm{ml})$ and ether $(10 \mathrm{ml})$ was added dropwise butyllithium $(1.6 \mathrm{M}$ in hexane, $5 \mathrm{ml})$ below $0^{\circ} \mathrm{C}$. The mixture was stirred at $0^{\circ} \mathrm{C}$ for $10 \mathrm{~min}$. To the mixture was added the dichlorovinyl amide $(0.70 \mathrm{~g})$ in dry THF $(5 \mathrm{ml})$ and ether $(5 \mathrm{ml})$ at $-70^{\circ} \mathrm{C}$. The mixture was stirred at -70 ${ }^{\circ} \mathrm{C}$ for $3 \mathrm{hr}$ and then allowed to rise to room temperature. After stirring overnight, the mixture was quenched with $2 \mathrm{~N} \mathrm{H}_{2} \mathrm{SO}_{4}$ and extracted with ether. The organic layer was washed with water, dried and concentrated. The residue was subjected to a preparative TLC on silica gel (developer, hexane-ethyl acetate $(5: 1, \mathrm{v} / \mathrm{v})$ ), followed by trituration with hexane-ether and filtration to give 4 ( 0.1 g, 18\%).

\subsection{Synthesis of $\alpha$-cyanoacetamide compounds}

$\alpha$-Cyanoacetamide compounds were prepared by one of the following six methods:

a) the reaction of the corresponding acid chlorides with the corresponding amines in the presence of a base.

b) the reaction of the corresponding amines with the 
a)

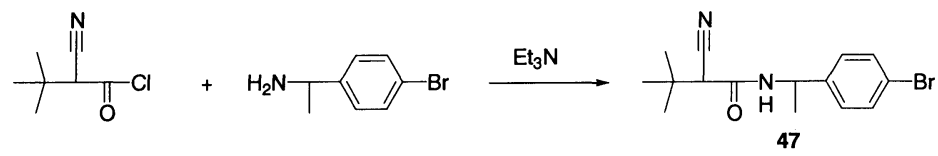

b)

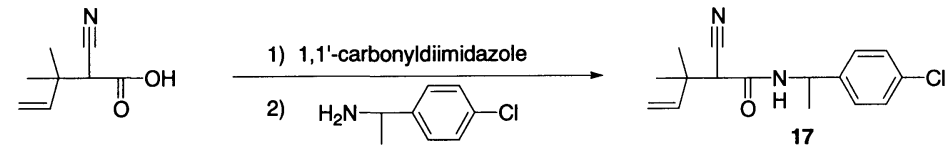

c)

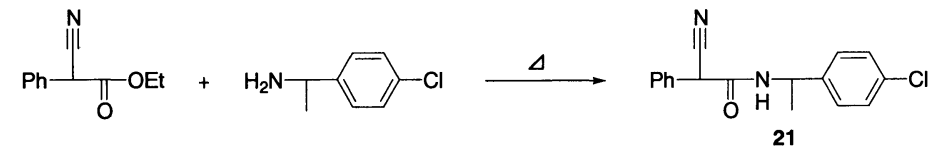

d)
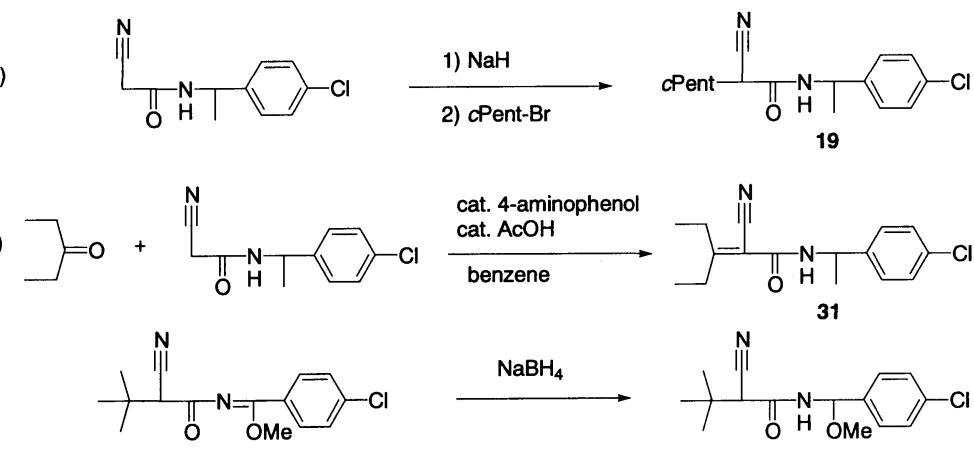

39

Fig. 2 Examples of $\alpha$-cyanoacetamide derivatives prepared by synthetic methods a to f.

corresponding acyl imidazoles which were prepared in situ by the reaction of the acid with 1,1'carbonyldiimidazole.

c) the reaction of the corresponding acid ethyl esters with the corresponding amines at elevated temperatures.

d) $\alpha$-alkylation or $\alpha$-bromination of the corresponding $\alpha$-cyanoacetamide compounds in the presence of a base.

e) the Knoevenagel-type condensation of $N$-[1-(4chlorophenyl)-ethyl]-2-cyanoethanamide with the corresponding ketones.

f) the reduction of an acyl imidate with $\mathrm{NaBH}_{4} \cdot{ }^{5)}$

Examples of the preparations obtained by these methods are shown in Fig. 2 and experimental details are as follows:

\subsection{1 a) $\mathrm{N}$-[1-(4-Bromophenyl)ethyl]-2-cyano-3,3-di- methylbutanamide 47}

To an ice-cooled solution of 1-(4-bromophenyl)ethylamine $(0.80 \mathrm{~g})$ and triethylamine $(0.48 \mathrm{~g})$ in dry ether (10 $\mathrm{ml})$ was added dropwise 2-cyano-3,3-dimethylbutanoyl chloride $(0.64 \mathrm{~g})$. After stirring at room temperature for $2 \mathrm{hr}$, the mixture was diluted with ether, washed with water, dried and concentrated. The residue was chromatographed on silica gel (eluent, hexane-ethyl acetate $(5: 1, \mathrm{v} / \mathrm{v}))$ to give $47(0.94 \mathrm{~g}, 73 \%)$.

\subsection{2 b) $\mathrm{N}$-[1-(4-Chlorophenyl)ethyl]-2-cyano-3,3-dime- thyl-4-pentenamide 17}

To a solution of 2-cyano-3,3-dimethyl-4-pentenoic acid
$(0.76 \mathrm{~g})$ in dry THF $(5 \mathrm{ml})$, was added $1,1^{\prime}$-carbonyldiimidazole $(0.97 \mathrm{~g})$ in small portions. The mixture was stirred at room temperature for $1 \mathrm{hr}$. To this solution was added dropwise 1-(4-chlorophenyl)ethylamine (0.78 $\mathrm{g}$ ) and the stirring was continued at room temperature for $2 \mathrm{hr}$. The mixture was diluted with ether and washed successively with $\mathrm{HCl}$ aq., sat. $\mathrm{NaHCO}_{3}$ and sat. brine, dried and concentrated. The residue was chromatographed on silica gel (eluent, hexane-ethyl acetate $(5: 1, \mathrm{v} /$ v)) to give $17(0.72 \mathrm{~g}, 50 \%)$.

\subsection{3 c) $\mathrm{N}$-[1-(4-Chlorophenyl)ethyl]-2-cyano-2-phenyl- ethanamide 21}

A mixture of ethyl 2-cyano-2-phenylethanoate $(0.98 \mathrm{~g})$ and 1-(4-chlorophenyl)ethylamine $(0.78 \mathrm{~g})$ was stirred at $150-160^{\circ} \mathrm{C}$ for $1 \mathrm{hr}$, while removing the ethanol produced. The mixture was chromatographed on silica gel (eluent, hexane-ethyl acetate $(5: 1, \mathrm{v} / \mathrm{v}))$ to give 21 $(1.0 \mathrm{~g}, 67 \%)$.

\section{2 .4 d) $\mathrm{N}$-[1-(4-Chlorophenyl)ethyl]-2-cyano-2-cyclo- pentylethanamide 19}

To an ice-cooled solution of $N$-[1-(4-chlorophenyl)ethyl]-2-cyanoethanamide $(0.89 \mathrm{~g})$ in dry DMF $(5 \mathrm{ml})$ was added sodium hydride $(60 \%$ in oil, $0.17 \mathrm{~g})$ under $\mathrm{N}_{2}$. The mixture was stirred with ice-cooling for $0.5 \mathrm{hr}$. To this solution was added dropwise cyclopentyl bromide $(0.73 \mathrm{~g})$ and the stirring was continued at room temperature for $4 \mathrm{hr}$. The mixture was treated with water and extracted with ethyl acetate. The organic layer was washed twice with brine, dried and concentrated. The 
residue was chromatographed on silica gel (eluent, hexane-ethyl acetate $(5: 1, \mathrm{v} / \mathrm{v}))$ to give $19(0.58 \mathrm{~g}, 50 \%)$. 1.2 .5 e) $\mathrm{N}$-[1-(4-Chlorophenyl)ethyl]-2-cyano-3-ethyl-2pentenamide 31

A mixture of $N$-[1-(4-chlorophenyl)ethyl]-2-cyanoethanamide $(2.22 \mathrm{~g}), 3$-pentanone $(5 \mathrm{ml})$, glacial acetic acid $(0.2 \mathrm{~g})$, benzene $(10 \mathrm{ml})$ and 4-aminophenol $(28 \mathrm{mg})$ was stirred at reflux for $3 \mathrm{hr}$, while removing the water produced. The mixture was filtered through Celite, washed with $\mathrm{CHCl}_{3}$ and concentrated. The residue was chromatographed on silica gel (eluent, hexane-ethyl acetate $(5: 1, \mathrm{v} / \mathrm{v}))$ to give $31(1.87 \mathrm{~g}, 64 \%)$.

\subsection{6 f) $\mathrm{N}-[1$-(4-Chlorophenyl)-1-methoxymethyl]-2- cyano-3,3-dimethylbutanamide 39}

To an ice-cooled solution of methyl 4-chlorobenzenecarboximidate $\left.^{6}\right)(1.70 \mathrm{~g})$ and triethylamine $(1.24 \mathrm{~g})$ in dry toluene $(15 \mathrm{ml})$ was added dropwise a solution of 2cyano-3,3-dimethylbutanoyl chloride in dry toluene (5 $\mathrm{ml}$ ). After stirring at room temperature for $12 \mathrm{hr}$, the mixture was cooled in an ice bath, filtered and washed with toluene. The filtrate was concentrated to give methyl 4-chloro- $N$-(2-cyano-3,3-dimethylbutanoyl)benzenecarboximidate $(3.09 \mathrm{~g})$.

To an ice-cooled mixture of the acylimidate $(1.17 \mathrm{~g})$ in methanol $(7 \mathrm{ml})$ was added $\mathrm{NaBH}_{4}(0.17 \mathrm{~g})$. The mixture was stirred with ice cooling for $10 \mathrm{~min}$, poured into an ice- cooled solution of $1 \%$ aq. acetic acid $(50 \mathrm{ml})$ and extracted with ether. The organic layer was washed successively with $\mathrm{NaHCO}_{3}$ aq. and brine, dried and concentrated. The residue was chromatographed on silica gel (eluent, hexane-ethyl acetate $(2: 1, \mathrm{v} / \mathrm{v}))$ to give 39 (0.53 g, 45\%).

\subsection{Synthesis of acids and esters}

The $\alpha$-substituted cyanoacetic acids and their esters were prepared as described in the literature, ${ }^{7-10)}$ except the ester shown below.

\subsubsection{Ethyl 1-cyano-2,2-dimethylcyclopropanecarboxyl- ate}

To a mixture of sodium hydride ( $60 \%$ in oil, $0.42 \mathrm{~g}$ ) in dry DMF $(20 \mathrm{ml})$ was added trimethylsulfoxonium iodide $(2.25 \mathrm{~g})$ under $\mathrm{N}_{2}$. The mixture was stirred at room temperature for $15 \mathrm{~min}$. To the mixture was added ethyl 2-cyano-3-methylbutenoate $(1.53 \mathrm{~g})$ in dry DMF ( $5 \mathrm{ml})$. After stirring at room temperature for 1 $\mathrm{hr}$, the mixture was poured into ice-water, extracted with ether, washed twice with brine, dried and concentrated. The residue was chromatographed on silica gel (eluent: hexane-ethyl acetate $(5: 1, \mathrm{v} / \mathrm{v}))$ to give the desired ester (0.88 g, 53\%).

\subsection{Synthesis of amines}

Both 1-(2-chloro-5-pyridyl)ethylamine and 1-(3-chloro-6-pyridyl)ethylamine were prepared from the corresponding O-methyl oxime ethers by reduction with $\mathrm{BH}_{3}$. $\mathrm{S}(\mathrm{Me})_{2}$. All 1-(substituted-phenyl or -thienyl)ethylamines were prepared from the corresponding ketones by the Leukart reaction ${ }^{11)}$ as exemplified below:

\subsubsection{1-(4-Chloro-2-methoxyphenyl)ethylamine}

A mixture of 4-chloro-2-methoxyacetophenone (7.43 $\mathrm{g})$, formamide $(7.48 \mathrm{~g})$ and $90 \% \mathrm{aq}$. formic acid ( $1 \mathrm{ml})$ was heated at $180-190^{\circ} \mathrm{C}$. The mixture was treated with water and extracted with $\mathrm{CHCl}_{3}$. The organic layer was concentrated. To the residue was added conc. $\mathrm{HCl}$ and the mixture was stirred at $100^{\circ} \mathrm{C}$ (bath temperature) for $1 \mathrm{hr}$. The mixture was treated with water with icecooling, and extracted twice with $\mathrm{CHCl}_{3}$. The aqueous layer was made alkaline by adding $\mathrm{NaOH}$ aq. with ice-cooling, extracted twice with ether, dried and concentrated to give the desired amine $(5.24 \mathrm{~g}, 70 \%)$.

\subsection{Preparation of stereoisomers}

Each of the four stereoisomers constituting the compound 56 was directly isolated from 56 by preparative HPLC. The conditions for the isolation were as follows: Apparatus: HITACHI L-6200; Column: SUMIPAX YMC-GEL SIL 120A (5 $\mu \mathrm{m}, 4 \mathrm{~mm}$ diameter $\times 25 \mathrm{~cm}$ length $)+$ SUMICHIRAL OA-4700 $(5 \mu \mathrm{m}$, $4.6 \mathrm{~mm}$ diameter $\times 25 \mathrm{~cm}$ length); Mobile phase: hexane/ ethanol/trifluoroacetic acid $=240: 10: 1$; Detection: UV $254 \mathrm{~nm}$.

Each of the four stereoisomers was named after the order eluted in the HPLC as 56a, 56b, 56c and 56d, respectively. The absolute configuration of each of the stereoisomers was determined as follows: the first eluent 56a was determined to be a $(R, R)$-configuration by $\mathrm{X}$-ray structural analysis. Furthermore, a mixture of the third and the fourth eluent $\mathbf{5 6 c}+\mathbf{5 6 d}$ was determined to be the $(R, S)+(S, R)$-configuration by $\mathrm{X}$-ray analysis. From these results, the remaining second eluent 56b was determined to be the $(S, S)$-configuration. On the other hand, the reaction of $(R)-1-(2,4-$ dichlorophenyl)ethylamine (obtained below) with ethyl $(R S)$-2-cyano-3,3-dimethylbutanoate at an elevated temperature gave a product 56e which was found to be identical with $\mathbf{5 6 a}+\mathbf{5 6 d}$ by analytical HPLC. Therefore, 56c and 56d were determined to be the $[(R)$ acid, $(S)$ amine $]$ and $[(S)$ acid, $(R)$ amine] configuration, respectively.

\subsection{1 (R)-(+)-1-(2,4-Dichlorophenyl)ethylamine}

To a mixture of water (1.21) and 95\% ethanol (2.81) were added L-aspartic acid (Special Grade Reagent available from Wako Pure Chemical Industries, Ltd.; chemical purity $\left.>99.0 \% ;[\alpha]_{\mathrm{D}}=+24.9-25.8^{\circ}\right)$ and $(R S)-1-(2$, 4-dichlorophenyl)ethylamine $(76.5 \mathrm{~g})$, and the mixture was heated at reflux with stirring for $1 \mathrm{hr}$. While stirring was continued, the solution was allowed to cool to $40^{\circ} \mathrm{C}$ and then cooled to $20^{\circ} \mathrm{C}$ in a water bath. The solution was stirred at $23^{\circ} \mathrm{C}$ for $30 \mathrm{~min}$, and the resulting crystals were collected by filtration, washed with chilled ethanol $(100 \mathrm{ml})$ and dried to give white crystals $(25.6 \mathrm{~g})$, which were recrystallized from $50 \%$ aq. ethanol $(200 \mathrm{ml})$ to give $(+)-1-(2,4-$ dichlorophenyl)ethylamine Laspartate $(20.4 \mathrm{~g})$. These were treated with $20 \%$ aq. 
$\mathrm{NaOH}(100 \mathrm{ml})$, and the liberated amine was extracted with toluene. The organic layer was dried and concentrated to give $(R)-(+)-1-(2,4$-dichlorophenyl)ethylamine $(11.9 \mathrm{~g}) ;[\alpha]_{\mathrm{D}}^{24}=+44.86^{\circ}(c=1.114)$. The optical purity was $99.9 \%$ ee by HPLC analysis under the following conditions: Apparatus: HITACHI L-6200; Column: SUMICHIRAL OA-4100 $\quad(6 \mathrm{~mm} \quad$ diameter $\times 25 \mathrm{~cm}$ length); Mobile phase: hexane/ethanol/trifluoroacetic acid $=240: 10: 1$; Detection: UV $254 \mathrm{~nm}$. The absolute configuration of the amine was determined to be $(R)$ as follows: The resolved amine was reacted with $(R S)-2-$ cyano-3,3-dimethylbutanoyl imidazole to give a diastereomeric mixture, part of which was determined to be (R)-2-cyano- $N$ - $[(R)$-1-(2,4-dichlorophenyl)ethyl $]-3,3-d i-$ methylbutanamide by X-ray analysis. Therefore, the absolute configuration of the resolved amine was determined to be $(R)$.

\section{Biological Tests}

\subsection{Preventive activity against rice blast}

\subsubsection{Method A: Preventive activity in the foliar spray} test

Sandy loam soil was placed in plastic pots $(5 \mathrm{~cm}$ in diameter, $90 \mathrm{ml}$ in volume), and rice (var., Nihonbare) was sowed and cultivated into seedlings for 20 days in a greenhouse. The emulsifiable concentrate of each test compound was diluted with water to a prescribed concentration $(400,200,50,12.5$ or $3.1 \mathrm{ppm} ; 25,6.3,1.6$ or 0.4 ppm) and applied to the seedlings. The seedlings were air-dried and inoculated by spraying a conidial suspension of Magnaporthe grisea. The seedlings were cultivated in a greenhouse for 8 days under dark and highly humid conditions at $20^{\circ} \mathrm{C}$ in the nighttime and under light and slightly humid conditions at $24^{\circ} \mathrm{C}$ in the daytime to examine the control. The activity to control the disease was assessed by visual observation of the disease severity in test plants, i.e., the extent of damage to the leaves and stems, and represented in most cases by the 5 ranks of S, A, B, C and D based on the concentration giving $10 \%$ or less lesions, i.e., " $\mathrm{S}$ " for $3.1 \mathrm{ppm}$; " $\mathrm{A}$ " for 12.5 ppm; "B" for 50 ppm; "C" for 200 ppm; "D" for less active than $\mathrm{C}$. In some cases the activity was represented by the following 6 ranks, i.e., " 5 " for $0 \%$ damage; " 4 " for $10 \%$; " 3 " for $30 \%$; " 2 " for $50 \%$; " 1 " for $70 \%$; " 0 " for more than $70 \%$ with no difference from the disease severity of the untreated plots.

\subsubsection{Method B: Preventive activity in the soil drench test}

Sandy loam soil was placed in plastic pots $(5 \mathrm{~cm}$ in diameter, $90 \mathrm{ml}$ in volume), and rice (var., Nihonbare) was sowed and cultivated into seedlings for 14 days in a greenhouse. The emulsifiable concentrate of each test compound was diluted with water and the soil was drenched with a prescribed amount $(2,1,0.25,0063 \mathrm{mg} /$ pot) of this aqueous solution. The seedlings were culti- vated for 7 days in a greenhouse, and then inoculated and cultivated as described for method A. The activity to control the disease was determined as described for method A, and ranked as A, B, C and D based on the dosage giving $10 \%$ or less lesions, i.e., "A" for $0.063 \mathrm{mg} /$ pot; "B" for $0.25 \mathrm{mg} /$ pot; "C" for $1 \mathrm{mg} /$ pot; "D" for less active than $\mathrm{C}$.

\subsubsection{Method C: Preventive effect of the seedling box treatment}

Seedling boxes for rice $(30 \mathrm{~cm} \times 60 \mathrm{~cm} \times 3 \mathrm{~cm})$ were filled with soil (Bonsol No. 2, available from Koura Sangyo Co., Ltd.) and sowed with germinated rice seeds (var. Nihonbare) at $200 \mathrm{~g}$ per box. Twenty days after the seeding, a granule formulation of each test compound was uniformly distributed over the surface of the seedbed in the seedling boxes. Five rice seedlings were then transplanted in a Wagner pot (1/5000 are), which had been filled with sandy loam soil and flooded with water. The rice seedlings were cultivated in a greenhouse with the water leaking from the bottom of the Wagner pot at a rate of $3 \mathrm{~cm}$ per day. Four or six weeks after the transplanting, these rice seedlings, together with other rice seedlings which were previously inoculated with Magnaporthe grisea, were placed under a plastic cover and maintained in a moistened state to infect them with the fungus. After eleven days, the rice seedlings were examined and an index of disease attack by leaf rice blast was established based on the following criteria to determine the control value using the Equations 1 and 2 . The disease attack ratio in the non-treated plants was $91 \%$ and $95 \%$, respectively, when the period from transplant to infection was four and six weeks. The criteria of disease attack were as follows: Disease attack index " 0 ": lesion area $0 \%$; Disease attack index 1: $1 \%$ to $5 \%$; Disease attack index " 2 ": $6 \%$ to $25 \%$; Disease attack index " 4 ": $26 \%$ to 50 \%; Disease attack index " 8 ": $51 \%$ or higher.

(Equation 1)

$$
\begin{aligned}
& \text { Disease attack ratio }(\%) \\
& =\{[(1 \times n 1)+(2 \times n 2)+(4 \times n 3) \\
& \quad+(8 \times n 4)] / 8 \times N\} \times 100
\end{aligned}
$$

where $\mathrm{N}$ is the total number of leaves examined and $\mathrm{n} 1$ to $\mathrm{n} 4$ are the numbers of leaves having a disease attack index of 1,2,4 and 8, respectively.

(Equation 2)

$$
\begin{aligned}
& \text { Control value }(\%) \\
& =\frac{\left(\begin{array}{c}
(\text { Dar in non-treated field }) \\
-(\text { Dar in treated field })
\end{array}\right)}{\text { Dar in non-treated field }} \times 100
\end{aligned}
$$

where Dar stands for Disease attack ratio (\%).

\subsection{Inhibitory potency of melanization}

\section{Method $D$}

Each of the test compounds dissolved in DMSO was added to an agar medium in a petri dish to prepare an 
agar plate. On the agar plate was placed a piece of cellophane paper, which was then inoculated with the conidial suspension of Magnaporthe grisea. After incubation at $27^{\circ} \mathrm{C}$ for two days, the inhibitory potency of the fungal appressorial melanization was evaluated by observing color changes microscopically.

\section{RESULTS AND DISCUSSION}

\section{Effect of the $\alpha$-Cyano Group}

Table 1 shows the fungicidal activity against rice blast of a variety of 2-substituted- $N$-[1-(4-chlorophenyl)ethyl]-3,3-dimethylbutanamides. These 2-substituents were selected in order to improve the hydrophilicity of the molecule. As reported earlier, ${ }^{1}{ }^{1}$ the bromine derivative 1 showed good activity in a foliar spray test, but its activity in a soil drench test was found to be moderate. In marked contrast to $\mathbf{1}$, the nitrile derivative $\mathbf{5}$ was found to be highly effective both in the foliar spray test and in the soil drench test, demonstrating that $\mathbf{5}$ has excellent systemic activity as well as excellent fundamental fungicidal activity. No remarkable activity was observed in other derivatives having a methylsulfenyl (2), a fluoro (3), an ethynyl (4), a methoxy (6), a hydroxy (7), a methylsulfinyl (8) and a methylsulfonyl group (9) as an $\alpha$-substituent. It is noteworthy that the ethynyl derivative 4 shows only weak activity even in the foliar spray test, in view of the fact that the ethynyl group is well known as a structural analogue of the cyano group and that the pyrethroid insecticide empenthrin with an ethynyl group was far more active than its cyano analogue in a fundamental insecticidal test. ${ }^{12)}$ Moreover, the compact and electron-withdrawing fluorine (3) is far less suited to the $\alpha$-substituent even in comparison with

Table 1 2-Substituted- $N$-[1-(4-chlorophenyl)ethyl]-3,3-dimethylbutanamides and their preventive activity against rice blast.

\begin{tabular}{|c|c|c|c|c|}
\hline \multicolumn{3}{|c|}{ Compound } & \multicolumn{2}{|c|}{ Preventive Activity } \\
\hline No. & $x$ & $\mathrm{mp}\left({ }^{(} \mathrm{C}\right)$ & $\begin{array}{l}\text { Foliar } \\
\text { Spray }^{\text {c) }}\end{array}$ & $\begin{array}{l}\text { Soil } \\
\text { Drench }\end{array}$ \\
\hline $\begin{array}{l}1 \\
2 \\
3 \\
4 \\
5 \\
61^{a)} \\
6 m^{\text {b) }} \\
71^{a)} \\
7 m^{\text {a) }} \\
8 \\
9\end{array}$ & $\begin{array}{l}\mathrm{Br} \\
\mathrm{SMe} \\
\mathrm{F} \\
\mathrm{C}=\mathrm{CH} \\
\mathrm{CN} \\
\mathrm{OMe} \\
\mathrm{OMe} \\
\mathrm{OH} \\
\mathrm{OH} \\
\mathrm{S}(\mathrm{O}) \mathrm{Me} \\
\mathrm{S}(\mathrm{O})_{2} \mathrm{Me}\end{array}$ & $\begin{array}{l}106-108 \\
117-119 \\
63-67 \\
100-105 \\
99-103 \\
70-72.5 \\
115-118 \\
102 \\
159 \\
119-121 \\
140-145\end{array}$ & $\begin{array}{l}\text { A } \\
C \\
D \\
C \\
\text { C } \\
D \\
C \\
C \\
C \\
D \\
D \\
C\end{array}$ & $\begin{array}{l}\text { C } \\
\text { D } \\
\text { D } \\
D \\
\text { D } \\
\text { D } \\
\text { D } \\
\text { D } \\
\text { D } \\
D \\
D\end{array}$ \\
\hline
\end{tabular}

a) The less polar diastereomer on silica gel TLC developed by a hexane-ethyl acetate system. b) The more polar diastereomer on silica gel TLC developed by a hexane-ethyl acetate system. ${ }^{\text {c) }}$ For the indexes of the activity and the experimental details, see the text (method A). d) For the indexes of the activity and the experimental details, see the text (method B). bromine (1). These facts suggest that the hydrogenbonding ability of the nitrogen atom in the cyano group together with its ability to impart hydrophilicity contributes to the remarkably high activity.

\section{Effect of the $\alpha$-Alkyl Group}

Table 2 shows the fungicidal activity of a wide range of 2-substituted- $N$-[1-(4-chlorophenyl)ethyl]-2-cyanoacetamides. The activity was found to be greatly influenced by the $\alpha$-alkyl group. The 2-ethylpropyl (15), 1,1-dimethyl-2-propenyl (17) and 1,1-dimethyl-2propynyl (18) derivatives showed activity comparable to the tert-butyl derivative 5. By contrast, the isopropyl (11), $n$-butyl (12), isobutyl (13), sec-butyl (14), neopentyl (16), cyclopentyl (19) and cyclohexyl (20) derivatives were less active. The methyl (10) and phenyl (21) derivatives were inactive even at $400 \mathrm{ppm}$ and $1 \mathrm{mg} /$ pot.

No highly active compound was found in 2,2disubstituted- $N$-[1-(4-chlorophenyl)ethyl]-2-cyanoacetamides such as $\alpha, \alpha$-dialkyl derivatives (22 to $\mathbf{2 4}, \mathbf{2 6}$ ), the $\alpha$-alkyl- $\alpha$-bromo derivative (25), cyclic derivatives (2729) and $\alpha$-alkylidene derivatives (30-33), as shown in Table 3. These results suggest the importance of the presence of $\alpha$-hydrogen for activity.

\section{Effect of the Amine Moiety}

Table 4 shows the fungicidal activity of $N$-substituted2-cyano-3,3-dimethylbutanamides. The high level of activity shown by the $\alpha$-methyl-4-chlorobenzyl derivative 5 was almost lost on transformation of the $\alpha$-methyl-4chlorobenzyl group to alkyl $(\mathbf{3 4}, \mathbf{3 5})$, aryl (36) and

Table 2 2-Substituted- $N$-[1-(4-chlorophenyl)ethyl]-2cyanoacetamides and their preventive activity against rice blast.

\begin{tabular}{|c|c|c|c|c|c|}
\hline \multicolumn{4}{|c|}{ Compound } & \multicolumn{2}{|c|}{ Preventive Activity } \\
\hline No. & $\mathrm{R}^{1}$ & $\begin{array}{l}\text { Synthetic } \\
\text { Method }^{\text {a) }}\end{array}$ & $\mathrm{mp}\left({ }^{\circ} \mathrm{C}\right)$ & $\begin{array}{l}\text { Foliar } \\
\text { Sprayb) }^{\text {b) }}\end{array}$ & $\begin{array}{l}\text { Soil } \\
\text { Drench }\end{array}$ \\
\hline \begin{tabular}{|l|l|}
10 \\
11 \\
12 \\
13 \\
14 \\
14 \\
5 \\
15 \\
16 \\
17 \\
18 \\
19 \\
20 \\
21
\end{tabular} & $\begin{array}{l}\mathrm{Me} \\
\mathrm{Pr} \\
\mathrm{nBu} \\
\mathrm{Bu} \\
s \mathrm{Bu} \\
\mathrm{iBu} \\
(\mathrm{Et})_{2} \mathrm{CH} \\
\mathrm{tBuCH}_{2} \\
\left(\mathrm{H}_{2} \mathrm{C}=\mathrm{CH}\right) \mathrm{C}(\mathrm{Me})_{2} \\
(\mathrm{HC} \equiv \mathrm{C}) \mathrm{C}(\mathrm{Me})_{2} \\
\text { CPent } \\
\text { cHex } \\
\mathrm{Ph}\end{array}$ & $\begin{array}{l}c \\
d \\
d \\
d \\
a \\
a \\
d \\
b \\
b \\
b \\
d \\
d \\
c\end{array}$ & $\begin{array}{l}114-116 \\
89-92 \\
77-79 \\
122-125 \\
78-82 \\
99-103 \\
73-76 \\
81-83 \\
102-105 \\
147-149 \\
106-108 \\
149-152 \\
134-136\end{array}$ & $\begin{array}{l}\text { D } \\
\text { C } \\
\text { B } \\
\text { C } \\
\text { B } \\
\text { S } \\
\text { S } \\
\text { C } \\
\text { S } \\
\text { S } \\
\text { B } \\
\text { C } \\
\text { D }\end{array}$ & $\begin{array}{l}\text { D } \\
\text { B } \\
C \\
C \\
B \\
A \\
\text { B } \\
B \\
\text { A } \\
A \\
C \\
D \\
\text { D }\end{array}$ \\
\hline
\end{tabular}

a) For the indexes of the synthetic method and the experimental details, see the text. b) For the indexes of the activity and the experimental details, see the text $(\operatorname{method} A)$. ${ }^{c}$ For the indexes of the activity and the experimental details, see the text (method B). 
Table 3 2,2-Disubstituted- $N$-[1-(4-chlorophenyl)ethyl]-2cyanoacetamides and their preventive activity against rice blast.

\begin{tabular}{|c|c|c|c|c|c|}
\hline \multicolumn{4}{|c|}{ Compound } & \multicolumn{2}{|c|}{ Preventive Activity } \\
\hline No. & $\mathrm{R}^{1}$ & $\begin{array}{l}\text { Synthetic } \\
\text { Method }^{\text {a) }}\end{array}$ & $m p\left({ }^{\circ} \mathrm{C}\right)$ & $\begin{array}{l}\text { Foliar } \\
\text { Spray }^{\text {b) }}\end{array}$ & $\begin{array}{l}\text { Soil } \\
\text { Drench }\end{array}$ \\
\hline $\begin{array}{r}5 \\
22 \\
23 \\
24 \\
25 \\
26 \\
27 \\
28 \\
29 \\
30 \\
31 \\
32 \\
33\end{array}$ & $\begin{array}{lc}\mathrm{Bu} & \mathrm{H} \\
\mathrm{Me} & \mathrm{Me} \\
\mathrm{Pr} & \mathrm{Me} \\
\mathrm{Bu} & \mathrm{Me} \\
\mathrm{Bu} & \mathrm{Br} \\
\mathrm{Et} & \mathrm{Et} \\
-\mathrm{CH}_{2} \mathrm{CH}_{2} \mathrm{CH}_{2} \mathrm{CH}_{2^{-}} \\
-\mathrm{CH}_{2} \mathrm{CH}_{2} \mathrm{CH}_{2} \mathrm{CH}_{2} \mathrm{CH}_{2}^{-} \\
-\mathrm{CH}_{2}-\mathrm{C}(\mathrm{Me})_{2}^{-} \\
\mathrm{Me}(\mathrm{Me}) \mathrm{C}= & \\
\mathrm{Et}(\mathrm{Et}) \mathrm{C}= & \mathrm{CH}_{2} \mathrm{CH}_{2} \mathrm{C}= \\
\left(\mathrm{CH}_{2} \mathrm{CH}_{2} \mathrm{CH}_{2} \mathrm{CH}_{2}\right) & \left(\mathrm{CH}_{2} \mathrm{CH}_{2} \mathrm{CH}_{2} \mathrm{CH}_{2} \mathrm{CH}_{2}\right) \mathrm{C}=\end{array}$ & $\begin{array}{l}\text { a } \\
d \\
d \\
d \\
d \\
d \\
d \\
d \\
b \\
e \\
e \\
e \\
e\end{array}$ & $\begin{array}{l}99-103 \\
85-87 \\
96-98 \\
43-46 \\
70-72 \\
141-143 \\
90-92 \\
114-116 \\
133-136 \\
74-76 \\
67-69 \\
79-82 \\
78-80\end{array}$ & $\begin{array}{l}\text { S } \\
\text { D } \\
\text { D } \\
\text { C } \\
\text { C } \\
\text { D } \\
\text { D } \\
\text { D } \\
\text { D } \\
\text { D } \\
\text { B } \\
\text { C } \\
\text { D }\end{array}$ & $\begin{array}{l}\text { A } \\
D \\
D \\
D \\
B \\
D \\
D \\
D \\
D \\
D \\
D \\
C \\
C \\
D\end{array}$ \\
\hline
\end{tabular}

a) For the indexes of the synthetic method and the experimental details, see the text. ${ }^{\text {b) }}$ For the indexes of the activity and the experimental details, see the text (method A). ${ }^{c)}$ For the indexes of the activity and the experimental details, see the text (method B).

Table $4 \quad N$-Substituted-2-cyano-3,3-dimethylbutanamides and their preventive activity against rice blast.

\begin{tabular}{|c|c|c|c|c|c|}
\hline \multicolumn{4}{|c|}{ Compound } & \multicolumn{2}{|c|}{ Preventive Activity } \\
\hline No. & $R^{3}$ & $\begin{array}{l}\text { Synthetic } \\
\text { Method }^{\text {a }}\end{array}$ & $\mathrm{mp}\left({ }^{\circ} \mathrm{C}\right)$ & $\begin{array}{l}\text { Foliar } \\
\text { Spray }^{b}\end{array}$ & $\begin{array}{l}\text { Soil } \\
\text { Drench }^{\mathrm{c})}\end{array}$ \\
\hline $\begin{array}{r}34 \\
35 \\
36 \\
37 \\
58 \\
38 \\
39 \\
49 \\
41\end{array}$ & $\begin{array}{l}\mathrm{Pr} \\
\mathrm{CH}(\mathrm{Me})-\mathrm{Pr} \\
\mathrm{C}_{6} \mathrm{H}_{5}-4-\mathrm{Cl} \\
\mathrm{CH}_{2}-\mathrm{C}_{6} \mathrm{H}_{4}-4-\mathrm{Cl} \\
\mathrm{CH}_{4}(\mathrm{Me})-\mathrm{C}_{6} \mathrm{H}_{4}-4-\mathrm{Cl} \\
\mathrm{CH}(\mathrm{E}) \mathrm{Cl}-\mathrm{C}_{6} \mathrm{H}_{4}-4-\mathrm{Cl} \\
\mathrm{CH}(\mathrm{OMe})-\mathrm{C}_{6} \mathrm{H}_{4}-4-\mathrm{Cl} \\
\mathrm{CH}_{2} \mathrm{CH}_{2}-\mathrm{C}_{6} \mathrm{H}_{4}-4-\mathrm{Cl} \\
\mathrm{CH}(\mathrm{Me})-\mathrm{CH}_{2}-\mathrm{C}_{6} \mathrm{H}_{4}-4-\mathrm{Cl}\end{array}$ & $\begin{array}{l}\text { b } \\
\text { b } \\
\text { b } \\
c \\
\text { a } \\
\text { b } \\
\text { f } \\
\text { b } \\
c\end{array}$ & $\begin{array}{c}112-114 \\
124-127 \\
136-137 \\
134-137 \\
99-103 \\
163-166 \\
91-93 \\
95-97 \\
95-98\end{array}$ & $\begin{array}{l}D \\
D \\
D \\
D \\
C \\
S \\
D \\
D \\
C \\
C \\
C\end{array}$ & $\begin{array}{l}D \\
D \\
D \\
D \\
C \\
A \\
D \\
D \\
D \\
D\end{array}$ \\
\hline 42 & $\mathrm{CH}(\mathrm{Me})-$ & b & $141-143$ & $\mathrm{D}$ & D \\
\hline 43 & $\mathrm{CH}(\mathrm{Me}) \longrightarrow$ & b & $50-55$ & c & D \\
\hline 44 & $\mathrm{CH}(\mathrm{Me})-$ & a & $126-128$ & c & D \\
\hline
\end{tabular}

a) For the indexes of the synthetic method and the experimental details, see the text. b) For the indexes of the activity and the experimental details, see the text (method A). c) For the indexes of the activity and the experimental details, see the text (method B).

aralkyl (37-44) derivatives. Weak activity was observed for 4-chlorobenzyl (37), 2-(4-chlorophenyl)ethyl (40), 2-(4-chlorophenyl)-1-methylethyl (41), 1-(2-chloro5-pyridyl)ethyl (43) and 1-(2-chloro-5-thienyl)ethyl (44)
Table $5 N$-[1-(Substituted phenyl)ethyl]-2-cyano-3,3-dimethyl-butanamides and -2-pentanamides and their preventive activity against rice blast.

\begin{tabular}{|c|c|c|c|c|c|}
\hline \multicolumn{4}{|c|}{ Compound } & \multicolumn{2}{|c|}{ Preventive Activity } \\
\hline No. & $(Y) n$ & $\mathrm{R}^{4}$ & $\mathrm{mp}\left({ }^{\circ} \mathrm{C}\right)$ & $\begin{array}{l}\text { Foliar } \\
\text { Spray }^{a)}\end{array}$ & $\begin{array}{l}\text { Soil } \\
\text { Drench }^{\text {b) }}\end{array}$ \\
\hline 45 & $\mathrm{H}$ & $\mathrm{Me}$ & $137-139$ & $\mathrm{C}$ & $\mathrm{D}$ \\
\hline 46 & $4-F$ & $\mathrm{Me}$ & $121-125$ & $\mathrm{C}$ & $\mathrm{D}$ \\
\hline 5 & $4-\mathrm{Cl}$ & $\mathrm{Me}$ & $99-103$ & $\mathrm{~S}$ & $A$ \\
\hline 47 & $4-\mathrm{Br}$ & $\mathrm{Me}$ & $102-104$ & $\mathrm{~s}$ & A \\
\hline 48 & $4-\mathrm{CF}_{3}$ & $\mathrm{Me}$ & $92-94$ & $\mathrm{~s}$ & B \\
\hline 49 & $4-\mathrm{Me}$ & $\mathrm{Me}$ & $80-83$ & $\mathrm{~s}$ & $\mathrm{~B}$ \\
\hline 50 & 4-OMe & $\mathrm{Me}$ & $142-145$ & $\mathrm{C}$ & $\mathrm{C}$ \\
\hline 51 & $4-\mathrm{OCHF}_{2}$ & $\mathrm{Me}$ & $110-115$ & $\mathrm{~B}$ & B \\
\hline 52 & $4-\mathrm{OCF}_{3}$ & $\mathrm{Me}$ & $91-94$ & B & B \\
\hline 53 & $4-\mathrm{OCF}_{2} \mathrm{CF}_{2} \mathrm{H}$ & $\mathrm{Me}$ & $141-144$ & $\mathrm{C}$ & $\mathrm{C}$ \\
\hline 54 & $2-\mathrm{Cl}$ & $\mathrm{Me}$ & $161-162$ & D & $\mathrm{C}$ \\
\hline 55 & $3-\mathrm{Cl}$ & $\mathrm{Me}$ & $141-143$ & $\mathrm{C}$ & $\mathrm{C}$ \\
\hline 56 & $2,4-\mathrm{Cl}_{2}$ & $\mathrm{Me}$ & $186-188$ & $\mathrm{~s}$ & B \\
\hline 57 & $3,4-\mathrm{Cl}_{2}$ & $\mathrm{Me}$ & $146-148$ & B & $\mathrm{B}$ \\
\hline 17 & $4-\mathrm{Cl}$ & $\mathrm{CH}_{2}=\mathrm{CH}$ & $102-105$ & $\mathrm{~s}$ & $A$ \\
\hline 58 & $2-\mathrm{F}, 4-\mathrm{Cl}$ & $\mathrm{CH}_{2}=\mathrm{CH}$ & $115-118$ & $\mathrm{~s}$ & A \\
\hline 59 & $2,4-\mathrm{Cl}_{2}$ & $\mathrm{CH}_{2}=\mathrm{CH}$ & $153-155$ & A & B \\
\hline 60 & 2-Me,4-Cl & $\mathrm{CH}_{2}=\mathrm{CH}$ & 283 & D & $D$ \\
\hline 61 & 2-OMe,4-Cl & $\mathrm{CH}_{2}=\mathrm{CH}$ & $142-147$ & $\mathrm{~s}$ & B \\
\hline
\end{tabular}

a) For the indexes of the activity and the experimental details, see the text (method A). b) For the indexes of the activity and the experimental details, see the text (method B).

derivatives even in the foliar spray test. It is noted that even isosteric transformations as from methyl to ethyl (38), and from phenyl to pyridyl $(42,43)$ or thienyl (44), are detrimental to the activity.

\section{Effect of Phenyl Ring Substituents}

Table 5 shows the fungicidal activity of $N$-[1(substituted-phenyl)ethyl]-2-cyano-3,3-dimethylbutanamides and $N$-[1-(substituted-phenyl)ethyl]-2-cyano3,3-dimethyl-3-pentenamides. It seems clear from the table that the 4-substituent in the phenyl ring has an important role in the activity. Although the 4-chloro (5, 17), 4-bromo (47) and 2-fluoro-4-chloro (58) derivatives showed strong activity in both tests, they were also phytotoxic to rice plants at high concentrations. Thus, an extensive evaluation of highly active compounds such as 4-trifluoromethyl (48), 4-methyl (49), 2,4-dichloro (56), 4-chloro-2-methoxy (61) derivatives was conducted, and the 2,4-dichloro derivative $\mathbf{5 6}$ was selected for development based on fungicidal potency, lack of phytotoxicity and manufacturing cost.

\section{Steric Structure-Activity Correlation of $\mathbf{5 6}^{13)}$}

Compound 56 has two stereogenic centers, one in the acid moiety and another in the amine part. To examine the steric structure/biological activity relationships of the molecule, the four possible stereoisomers were isolated using preparative HPLC with optically active columns 
and the absolute configuration of each of the four isomers was determined as described in Materials and Methods (1.5 Preparation of stereoisomers).

As shown in Table 6, the stereoisomers with an $(R)$ configuration at the amine moiety $(\mathbf{5 6} \mathbf{6}, \mathbf{5 6 d})$ exhibited potent preventive activity, while those with an $(S)$ configuration $(\mathbf{5 6 b}, \mathbf{5 6 c})$ were inactive. The $[(S)$ acid, $(R)$ amine]-isomer (56d) was found to be most active, both in inhibiting fungal melanization (see the following section) and in pot tests on rice blast disease. On the other hand, it was found that racemization at the C-2 position of the acid moiety bearing the cyano group proceeds easily under basic conditions. Thus, the compound 56e (diclocymet, S-2900) having the $(R S)$ configuration at the acid moiety and the $(R)$ configuration at the amine moiety was selected and has been developed as a new systemic blast fungicide.

\section{Fungicidal Activity of Diclocymet 56e}

56e has superior preventive activity compared to the blast fungicide, fthalide (4,5,6,7-tetrachlorophthalide), as shown in Table 6. Furthermore, in Table 7 its remarkable residual preventive activity is noted in the seedling box treatment test, where 56e shows superior preventive activity compared to the systemic blast fungicide, tricyclazole (5-methyl-1,2,4-triazolo [3,4-b] benzothiazole), demonstrating that both the excellent systemic activity and the residual activity of 56e are highlighted in the seedling box treatment for rice blast control. Judging from the fact that 56e scarcely affects fungal mycelial growth in vitro and has no curative activity in pot tests in spite of its excellent preventive and systemic action, its mode of action is presumed to the inhibition of the fungal infection of rice plants. ${ }^{14)}$ Moreover, as seen in Table 6, it inhibits fungal melanization strongly in vitro without

Table 6 Stereoisomers of 2-cyano- $N$-[2,4-dichlorophenyl)ethyl]-3,3-dimethylbutanamides and their preventive activity against rice blast and inhibitory potency for appressorial melanization of the fungus.

\begin{tabular}{|c|c|c|c|c|c|c|c|c|}
\hline \multicolumn{4}{|c|}{ Compound } & \multicolumn{4}{|c|}{$\begin{array}{l}\text { Preventive Activity } \\
\text { Foliar Spray }\end{array}$} & \multirow{2}{*}{$\begin{array}{l}\text { Minimum inhibitory } \\
\text { concentration for } \\
\text { melanization }{ }^{\text {e) }} \\
\text { (ppm) }\end{array}$} \\
\hline No. & Isomer $(\star, \star \star \star)$ & $m p\left({ }^{\circ} \mathrm{C}\right)$ & {$[\alpha]_{0}^{25}$ in $\mathrm{CH}_{2} \mathrm{Cl}_{2}$} & 25 & 6.3 & 1.6 & $0.4 \mathrm{ppm}$ & \\
\hline $56 a$ & $(R, R)$ & $180-186$ & $+45.9^{\circ}(c=1.17)$ & 4 & 3 & 2 & 0 & $0.16-0.31$ \\
\hline $56 b$ & $(S, S)$ & $180-182$ & $-46.0^{\circ}(c=0.98)$ & 0 & 0 & 0 & 0 & $>20$ \\
\hline $56 c$ & $(R, S)$ & $173-174$ & $-1.4^{\circ}(c=0.96)$ & 0 & 0 & 0 & 0 & $>20$ \\
\hline $56 d$ & $(S, R)$ & $168-170$ & $+2.7^{\circ}(c=0.80)$ & 5 & 4 & 4 & 3 & $0.04-0.08$ \\
\hline $56 e^{a}$ & $(R S, R)$ & $160-161$ & $+18.0^{\circ}(c=1.01)^{c)}$ & 4 & 4 & 3 & 2 & $0.08-0.16$ \\
\hline 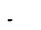 & fthalide $\theta^{\text {b) }}$ & - & - & 4 & 1 & 0 & 0 & $\cdot$ \\
\hline
\end{tabular}

a) Diclocymet (S-2900). b) A commercial rice blast furgicide. ${ }^{\text {c) }}$ Measured at $20^{\circ} \mathrm{C}$. d) For the indexes of the activity and the experimental details, see the text (method A). e) For the experimental details, see the text (method D).
Table 7 Preventive activity of diclocymet (S-2900) against rice blast by seedling box treatment.

\begin{tabular}{|c|c|c|c|c|c|c|c|}
\hline \multirow{2}{*}{\multicolumn{2}{|c|}{ Compound }} & \multicolumn{6}{|c|}{ Preventive Activity) } \\
\hline & & \multicolumn{2}{|c|}{4 weeks $^{c)}$} & \multicolumn{4}{|c|}{6 weeks $^{c)}$} \\
\hline No. & Common name & 1.5 & 0.75 & 3 & 2 & 1.5 & $0.75 \mathrm{~g} / \mathrm{box}^{\mathrm{d})}$ \\
\hline $56 e$ & diclocymet & 98 & 88 & 98 & - & 92 & 80 \\
\hline- & tricyclazole $^{a)}$ & - & - & - & 39 & - & - \\
\hline
\end{tabular}

a) A commercial systemic rice blast fungicide. b) For the indexes of the activity and the experimental details, see the text (method C). c) Period of time from transplant to infection with a rice blast pathogen. ${ }^{\text {d) }}$ Applied amount of active ingredient.

affecting the formation of the fungal appressoria. Therefore, its main mechanism of action was suggested to be the inhibition of melanin biosynthesis in the fungal appressoria. ${ }^{14)}$ In fact, scytalone, an intermediate of melanin biosynthesis, was found to be accumulated in the fungal fermentation medium that had been treated with 56e, suggesting that its target enzyme is scytalone dehydratase catalyzing the conversion of scytalone to 1,3 , 8 -trihydroxynaphthalene. ${ }^{14)}$ Recently, it has been reported that a structurally related amide compound, carpropamid(( $1 R, 3 S / 1 S, 3 R)$-2,2-dichloro- $N$ - $(R)$-1-(4chlorophenyl)ethyl-1-ethyl-3-methylcyclopropanecarboxamide), is also effective for rice blast control with a similar mode of action. ${ }^{15,16)}$ In the meanwhile, 56e has been registered in Japan and marketed as the rice blast fungicide, Delaus ${ }^{\circledR}$ by Sumitomo Chemical Co., Ltd., since April, 2000.

\section{ACKNOWLEDGMENTS}

We thank the late Dr. Osamu Kirino for his fruitful discussions in the initial stage of this work, Dr. Kazunori Yanagi for his X-ray analysis, Mr. Osamu Magara for his contribution to the stereoisomer study and Mr. Masamitsu Nire for his technical assistance.

\section{REFERENCES}

1) O. Kirino, C. Takayama and S. Inoue: J. Pesticide Sci. 12, 79-84 (1987).

2) W. J. Middleton: J. Org. Chem. 40, 574-578 (1975).

3) I. Hagedorn and U. Eholzer: Chem. Ber. 98, 936-940 (1965).

4) R. Appel, R. Kleinstück and K.-D. Ziehn: Angew. Chem. Int. Ed. 10, 132 (1971).

5) F. Matsuda, M. Yanagiya and T. Matsumoto: Tetrahedron Lett. 39, 4043-4046 (1982).

6) M. A. Pérez, C. A. Dorado and J. L. Soto: Synthesis, 483486 (1983).

7) E. R. Alexander and A. C. Cope: J. Am. Chem. Soc. 66, 886-888 (1944).

8) E. R. Alexander, J. D. McCollum and D. E. Paul: J. Am. Chem. Soc. 72, 4791-4792 (1950).

9) Res. Discl. 249, 55 (1985) (Disclosed anonymously). 
10) R. V. Stevens, N. Beaulieu, W. H. Chan, A. R. Daniewski, T. Takeda, A. Waldner, P. G. Williard and U. Zutter: $J$. Am. Chem. Soc. 108, 1039-1049 (1986).

11) M. L. Moore: "Organic Reactions," ed. by R. Adams et al., Vol. V, John Wiley \& Sons, Inc. pp. 301-330, 1949.

12) N. Matsuo, T. Yano, H. Yoshioka, S. Kuwahara, T. Sugai and K. Mori: "IUPAC Pesticide Chemistry, Human Welfare and the Environment," ed. by J. Miyamoto et al., Pergamon Press, Oxford, pp. 279-284, 1983.

13) A. Manabe, M. Enomoto, Y. Yamada, Y. Oguri and M. Sasaki: Pesticide Sci. 55, 649-650 (1999) (Extended Summaries: 9th International Congress of Pesticide Chemistry, London, 1998).

14) M. Soma, M. Sahara and Y. Oguri: Ann. Phytopathol. Soc. Jpn. 65, 401 (1999) (Abstracts of the Papers Presented at the Annual Meeting of Niigata, 1999) (in Japanese).

15) S. Kagabu and Y. Kurahashi: J. Pesticide Sci. 23, 145-147 (1998).

16) Y. Kurahashi, S. Kurogochi, N. Matsumoto and S. Kagabu: J. Pesticide Sci. 24, 204-216 (1999) (in Japanese).

\section{要 約 \\ $\alpha$-Cyanoacetamide 誘導体の合成と殺菌活性：新規 イネいもち病防除剤ジクロシメット(S-2900)の創製 \\ 真鍋明夫, 前田清人, 榎本雅行, 高野仁孝 加藤次裕, 山田好美, 小栗幸男}

新しいイネいもち病防除剂を見つけるため, 多くの $\alpha$-シ アノアセトアミド誘導体および関連化合物を合成し，イネ いもち病に対する予防効果を茎葉散布試験および灌注試験 で調べた.いくつかの $N-[1-($ 置換フェニル)エチル $]-2-シ$ アノ-3,3-ジメチル-ブタンアミドおよび-2-ペンテンアミ ドが両試験において高活性を示した。それらの中から，

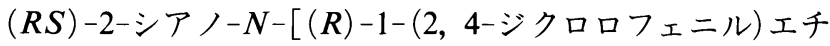
ル]-3, 3-ジメチルブチルアミド (ジクロシメット， S-2900) を浸透移行性を有する実用的なイネいもち病防除剂として 選抜した。 